\title{
Identification of the mechanism of NO reduction with ammonia (SCR) on zeolite catalysts
}

Authors: Konstantin Khivantsev, ${ }^{1, \dagger}, *$ Ja-Hun Kwak, ${ }^{2, \dagger, *}$ Nicholas R. Jaegers, ${ }^{1}$ Miroslaw A. Derewinski, ${ }^{1,3}$ Janos Szanyi, ${ }^{1, \dagger, *}$

\author{
Affiliations: \\ ${ }^{1}$ Institute for Integrated Catalysis, Pacific Northwest National Laboratory, Richland, WA 99352, \\ USA. \\ ${ }^{2}$ Ulsan National Institute of Science and Technology (UNIST), South Korea. \\ ${ }^{3}$ Jerzy Haber Institute of Catalysis and Surface Chemistry, Polish Academy of Sciences, Krakow \\ 30-239, Poland \\ * Correspondence to: K.K. E-mail: Konstantin.Khivantsev@pnnl.gov.J.-H. K. E-mail: \\ jhkwak@unist.ac.kr.J.Sz. E-mail: Janos.Szanyi@pnnl.gov; \\ $\dagger$ These authors contributed equally to the manuscript: KK, JHK, JSz
}

Short title: Clarification of the selective catalytic reduction mechanism

\begin{abstract}
Cu} /$ Zeolites catalyze selective catalytic reduction of nitric oxide with ammonia. Although the progress has been made in understanding the rate-limiting step of reaction which is reoxidation of $\mathrm{Cu}(\mathrm{I})\left(\mathrm{NH}_{3}\right)_{2}$ with oxygen to restore the catalytically active $\mathrm{Cu}(\mathrm{II})$ site, the exact $\mathrm{NO}$ reduction chemistry remained unknown. Herein, we show that nitrosyl ions $\mathrm{NO}^{+}$in the zeolitic micropores are the true active sites for NO reduction. They react with ammonia even at below/room temperature producing molecular nitrogen through the intermediacy of $\mathrm{N}_{2} \mathrm{H}^{+}$cation. Isotopic experiments confirm our findings. No copper is needed for this reaction to occur. However, when $\mathrm{NO}^{+}$reacts, “freed up” Bronsted acid site gets occupied by $\mathrm{NH}_{3}$ to form $\mathrm{NH}_{4}^{+}-$ and so the catalytic cycle stops because $\mathrm{NO}^{+}$does not form on $\mathrm{NH}_{4}$-Zeolites due to their acid sites being already occupied. Therefore, the role of $\mathrm{Cu}(\mathrm{II})$ in $\mathrm{Cu} / \mathrm{Zeolite}$ catalysts is to produce $\mathrm{NO}^{+}$by the reaction: $\mathrm{Cu}(\mathrm{II})+\mathrm{NO} \rightarrow \mathrm{Cu}(\mathrm{I})+\mathrm{NO}^{+}$which we further confirm spectroscopically. The $\mathrm{NO}^{+}$ then reacts with ammonia to produce nitrogen and water. Furthermore, when $\mathrm{Cu}(\mathrm{I})$ gets re-oxidized the catalytic cycle then can continue. Thus, our findings are critical for understanding complete SCR mechanism.
\end{abstract}

One Sentence Summary: We clarify the long-standing unknown SCR mechanism.

Air pollution is one of the main health and environmental concerns in our (post)industrial society [1-3]. Worsening air quality is tied to toxic nitric oxide (NO) gas, the majority of which is emitted by vehicles exhaust. The ability of $\mathrm{Cu} /$ zeolites to scrub $\mathrm{NO}$ in the presence of ammonia was first discovered in Japan in the 1960s [4] for Cu/FAU zeolite. However, FAU framework is less stable 
that the corresponding SSZ-13 and BEA zeolites [5]. Within the last decade, the ammonia selective catalytic reduction (SCR) technology was implemented on the large scale [5-19] for diesel engines on the basis of $\mathrm{Cu}(\mathrm{Fe})$ in BEA and SSZ-13 zeolites.

Remarkable advances have been achieved towards the goal of understanding the rate-limiting steps of the SCR mechanism [5-20]. Cu(II) ions are present in Cu/zeolite materials (they were shown to be more active and hydrothermally stable than $\mathrm{Cu}(\mathrm{II})-\mathrm{OH}$ ions [5-20,25]. The rate-limiting step for low-temperature SCR was shown to be re-oxidation of reduced $\mathrm{Cu}(\mathrm{I})\left(\mathrm{NH}_{3}\right)_{2}$ complexes via the formation of transient $\left(\mathrm{NH}_{3}\right)_{2} \mathrm{Cu}(\mathrm{II})-\mathrm{O}_{2}-\mathrm{Cu}(\mathrm{II})\left(\mathrm{NH}_{3}\right)_{2}$ dimers $[17,18]$. Despite that, the mechanism of the steps involving $\mathrm{NO}$ reduction with $\mathrm{NH}_{3}$ remained largely unknown [5-20]. We selectively formed $\mathrm{NO}^{+}$ion in $\mathrm{H}$-BEA zeolite (typical helium ion images of $\mathrm{H}-\mathrm{BEA}$ are shown in Fig. S6) by reaction of $\mathrm{NO}$ with sub-stoichiometric amounts of $\mathrm{O}_{2}$ [21-23](Fig. 1A).

$\mathrm{NO}^{+}$is formed through the following reaction ( $\underline{\text { Scheme } 1}$ responsible for spectra in Fig 1A):

$2 \mathrm{NO}+1 / 2 \mathrm{O}_{2}+2 \mathrm{H}$-Zeolite $\rightarrow 2 \mathrm{NO}^{+}+\mathrm{H}_{2} \mathrm{O}$

$\mathrm{NO}^{+}$occupies two different cationic positions with the corresponding $\mathrm{N}-\mathrm{O}$ stretching frequencies at 2133 and $\sim 2175 \mathrm{~cm}^{-1}$. The same type of chemistry also occurs on H-SSZ-13 (Fig. S1). Please note that adsorption of $\mathrm{NO}_{2}$ also produces $\mathrm{NO}^{+}$but with stoichiometric $\mathrm{NO}_{3}{ }^{-}$amounts due to $\mathrm{N}_{2} \mathrm{O}_{4}$ disproportionation (Fig. S2). Pulling the high vacuum $\left(\sim 10^{-7}\right.$ Torr) (with quick heating to $\left.150{ }^{\circ} \mathrm{C}\right)$ allows to remove excessive $\mathrm{NO}$ and $\mathrm{O}_{2}$, leaving zeolite with $\mathrm{NO}^{+}$adsorbed in it (Fig. 1B).

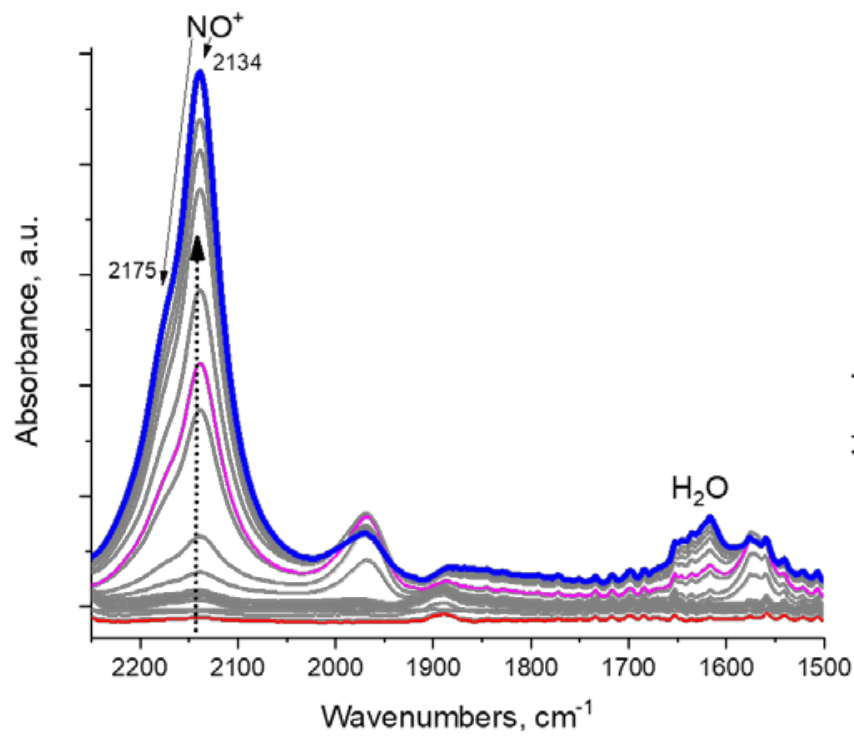

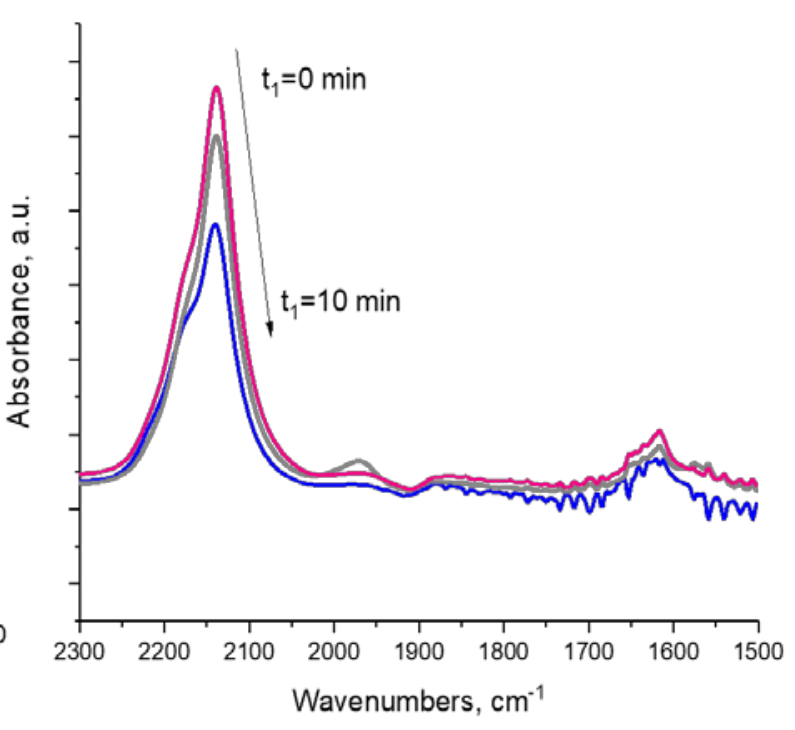


Fig.1 H-BEA Zeolite with Si/Al 15. A (left spectrum): in-situ FTIR during first sequential NO adsorption (0.1 Torr equilibrium pressure), followed by sequential $\mathrm{O}_{2}$ addition (0.17 Torr total eq. pressure - when $\mathrm{O}_{2}$ is added, $\mathrm{NO}^{+}$begins to develop in significant

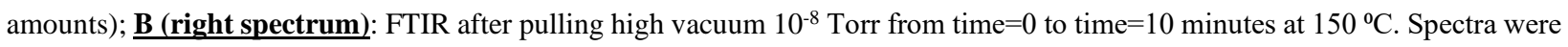
recorded after cooling back to $297 \mathrm{~K}$.

We exposed the $\mathrm{NO}^{+} /$Zeolite to ${ }^{15} \mathrm{~N}$-labeled ammonia at room temperature $297 \mathrm{~K}$ (Fig. 2A). Ammonia first occupies Bronsted acid sites forming $\mathrm{NH}_{4}{ }^{+}$complexes (which interact with more $\mathrm{NH}_{3}$ and the pores are filled with $\left(\mathrm{NH}_{3}\right)$ x cluster networks interacting with $\mathrm{NH}_{4}^{+}$ions [24,27]). During this, $\mathrm{NO}^{+}$reacts with ammonia, leaving no new visible NO stretches (Fig. 2A).
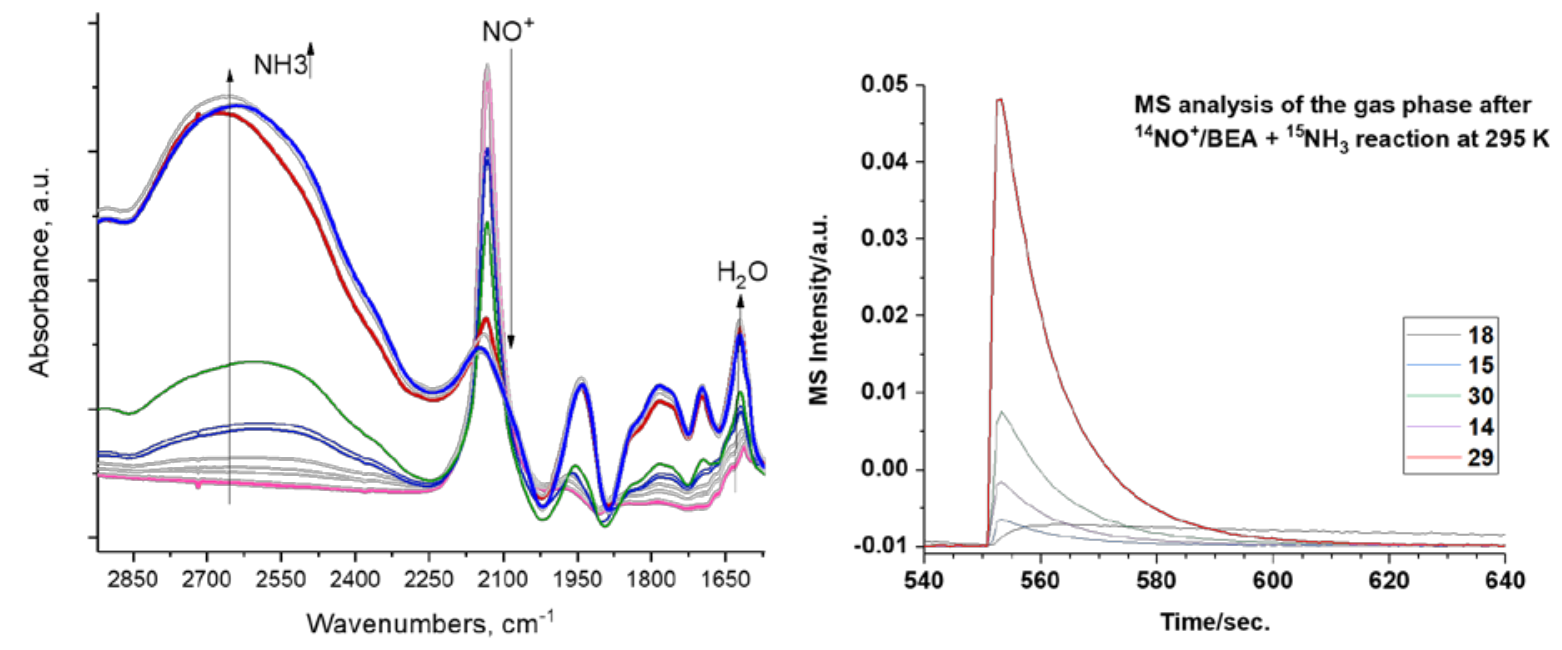

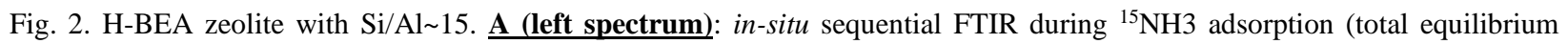
pressure 0.020 Torr) on $\mathrm{NO}^{+} / \mathrm{H}$-BEA sample at room temperature. Ammonia reacts with $\mathrm{NO}^{+}$. Gas phase from that reaction was analyzed with the mass spectrometer attached to the IR cell (Figure 2B shows formation of ${ }^{14} \mathrm{~N}^{15} \mathrm{~N}$ dinitrogen with the characteristic 29 mass signal).

The analysis of the gas-phase product with mass-spectrometry reveals a major peak at 29, corresponding to ${ }^{14} \mathrm{~N}-{ }^{15} \mathrm{~N}$ molecules (Fig. 2B). Thus, $\mathrm{NO}^{+}$reacts with ammonia with the formation of molecular nitrogen already at room temperature. Only the following sequence can be envisioned (Schemes 2 and 3 ) (note that $\mathrm{NO}^{+}$does not necessarily have to be bound to zeolite, it most likely is solvated by $\mathrm{NH}_{3}$; the designation Zeolite- $\mathrm{NO}^{+}$is just a representation of $\mathrm{NO}^{+} / \mathrm{H}$-zeolite system in which $\mathrm{NO}^{+}$may be solvated or semi-solvated by ammonia molecules):

Zeolite- $\mathrm{N}^{14} \mathrm{O}^{+}+\mathrm{N}^{15} \mathrm{H}_{3} \rightarrow$ Zeolite- $\mathrm{N}^{14} \mathrm{O}\left({ }^{15} \mathrm{NH}_{3}\right) \rightarrow\left[\right.$ Zeolite- $\left.\mathrm{N}^{14}(\mathrm{OH}) \mathrm{N}^{15} \mathrm{H}_{2}\right] \rightarrow$ Zeolite- $\left[{ }^{14 / 15} \mathrm{~N}_{2} \mathrm{H}^{+}\right]$ $+\mathrm{H}_{2} \mathrm{O}$ 
$\mathrm{N}_{2} \mathrm{H}^{+}$(hydronium diazonium cation) is extremely unstable. Its immediate decomposition to $\mathrm{N}_{2}$ and $\mathrm{H}$-Zeolite is what drives this reaction. Despite that, we find that at sufficiently high molecular $\mathrm{N}_{2}$ pressure in the cell ( 15 Torr) we can observe the $\mathrm{N}-\mathrm{N}$ stretch of $-\mathrm{HN}_{2}{ }^{+}$complex at $2334 \mathrm{~cm}^{-1}$ even at room temperature (Fig 3A), which was previously shown to form only at low temperatures upon $\mathrm{N}_{2}$ interaction with Bronsted acid sites (Fig. 3B) [26]. Thus, we can observe the intermediate of this reaction indirectly.
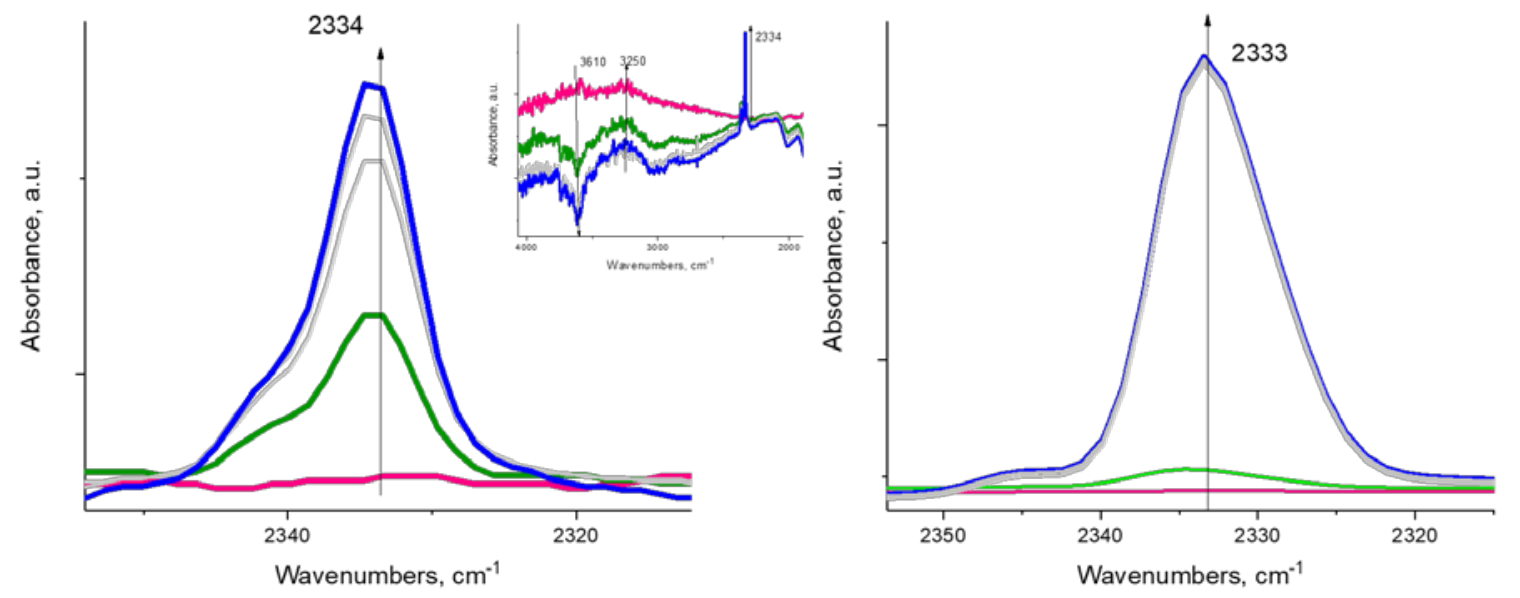

Fig. 3. A (left spectrum): in-situ FTIR during sequential dinitrogen $\mathrm{N}_{2}$ adsorption (equilibrium pressure $\sim 15$ Torr) on H-BEA at $298 \mathrm{~K}$. Zeolite-[ $\left[\mathrm{HN}_{2}{ }^{+}\right]$complex can be observed even at room temperature. Inset shows that $\mathrm{N}_{2}$ interacts with Bronsted acid sites of Si-OH-Al zeolite groups ( $\mathrm{OH}$ stretch of such groups is located at $\sim 3610 \mathrm{~cm}^{-1}$ ). $\underline{\mathbf{B}(\text { right }}$ spectrum): in-situ FTIR during Adsorption of only $~ 0.1$ Torr $\mathrm{N}_{2}$ on the same H-BEA tablet (equilibrium pressure is 0.001 Torr) at $77 \mathrm{~K}$ produces $\mathrm{N}-\mathrm{N}$ stretches of $\mathrm{N}_{2}$ adsorbed on Bronsted acid sites. Note that in this case even low equilibrium pressure of nitrogen produces intense N-N stretches.

To further prove the reaction proceeds through diazo compound, we chose aniline $\mathrm{PhNH}_{2}$ (which is equivalent to ammonia molecule but with 1 hydrogen atom substituted by a phenyl group) and reacted it with $\mathrm{NO}^{+}$in BEA zeolite. Phenyl group stabilizes the formation of $\mathrm{PhN}_{2}{ }^{+}$salts (phenyl diazonium salts) through the mesomeric effect, and thus, unlike alkyl diazonium salts, aryl diazonium compounds are stable and characterized by N-N stretches in $\sim 2,250-2,300 \mathrm{~cm}^{-1}$ region [28], more specifically $\sim 2,280 \mathrm{~cm}^{-1}$ for phenyl diazonium in solution [28]. Indeed, we monitored the reaction of $\mathrm{NO}^{+}$and $\mathrm{PhNH}_{2}$, spectroscopically: $\mathrm{NO}^{+}$band went down and a new N-N stretch appeared at $\sim 2270 \mathrm{~cm}^{-1}$, corresponding to the N-N vibration of Ph- $\mathrm{N}_{2}{ }^{+}$fragment (Fig. 4). 


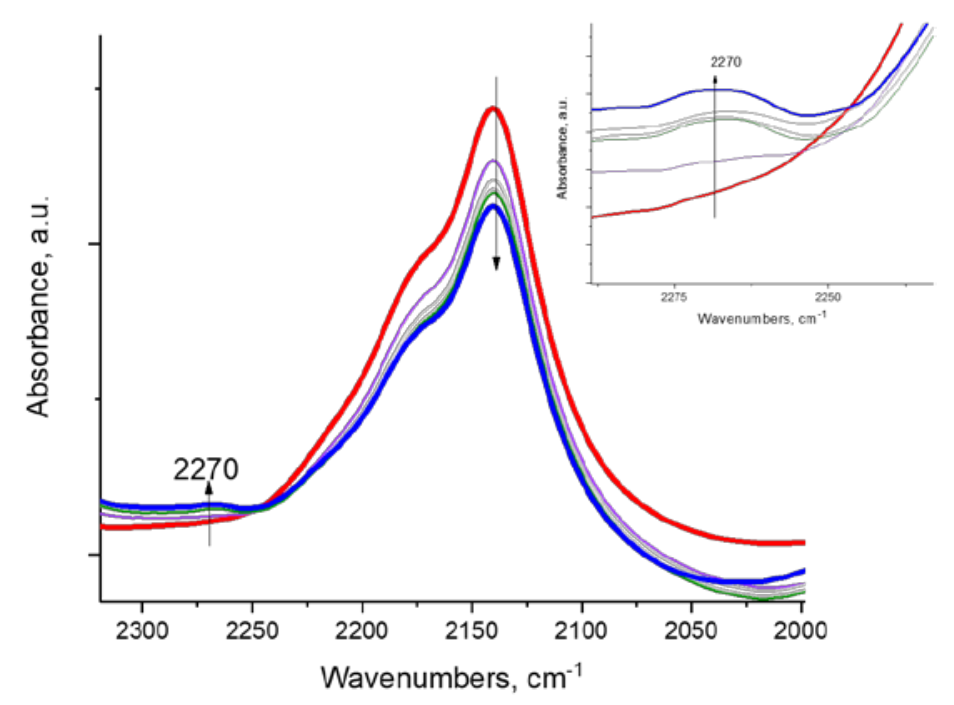

Fig. 4. in-situ FTIR during sequential $\sim 0.3$ Torr aniline $\mathrm{PhNH}_{2}$ adsorption (equilibrium pressure $\sim 0.03$ Torr) NO$/ \mathrm{H}-$ BEA.

$\mathrm{NO}^{+}$in H-SSZ-13 (with Si/Al 12; typical HAADF-STEM images of this sample are shown in Fig. S7) similarly reacts to $\mathrm{NH}_{3}$ (Fig. 5), with concomitant $\mathrm{N}_{2}$ evolution (confirmed with massspectrometry):

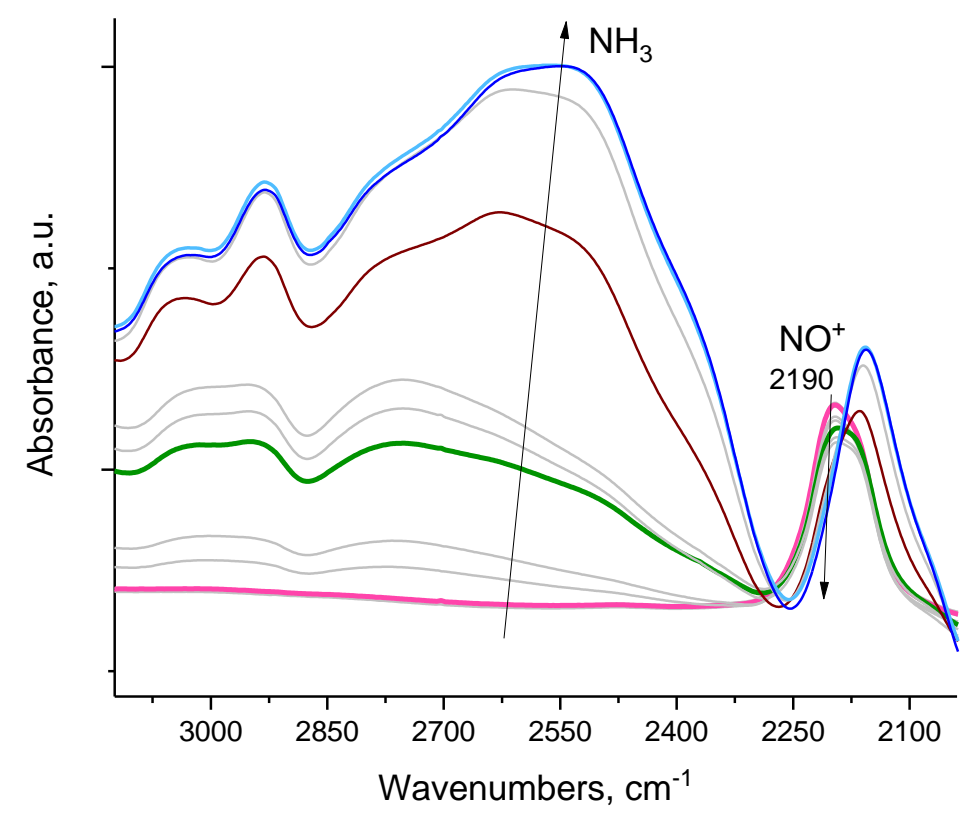

Fig. 5. H-SSZ-13 zeolite with Si/Al 12. In-situ sequential FTIR during ${ }^{14} \mathrm{NH}_{3}$ adsorption (total equilibrium pressure $\sim 0.15$ Torr) on $\mathrm{NO}^{+} / \mathrm{H}-\mathrm{SSZ}-13$ sample at room temperature. Ammonia reacts with $\mathrm{NO}^{+}$as evidenced by the disappearance of $\mathrm{NO}^{+}$ stretch. The intense band at $\sim 2110 \mathrm{~cm}^{-1}$ is due to zeolite interactions with $\mathrm{NH}_{3}$. Pulling vacuum on the sample at $120{ }^{\circ} \mathrm{C}$ produces spectra showing no $\mathrm{NO}^{+}$stretches (Fig. S3), consistent with complete reaction of $\mathrm{NO}^{+}$. 
Thus, $\mathrm{NO}^{+}$(which is produced from $\mathrm{NO}+\mathrm{O}_{2}$ reaction/it can also form from $\mathrm{N}_{2} \mathrm{O}_{4}$ disproportionation on zeolites if sufficient $\mathrm{NO}_{2}$ concentration is present [29]) is the critical intermediate in conversion of $\mathrm{NO}$ on zeolites. Copper is not even required to observe the $\mathrm{NO}^{+}$ reduction by $\mathrm{NH}_{3}$.

Moreover, we reacted inorganic nitrosyl salt $\mathrm{NO}^{+}$with ${ }^{15} \mathrm{NH}_{3}$ and observed ${ }^{14} \mathrm{~N}-{ }^{15} \mathrm{~N}$ in the gasphase (consistent with our findings for $\mathrm{NO}^{+}$in zeolites, this reaction takes place vigorously even at temperatures as low $\left.-50^{\circ} \mathrm{C}\right)$ ( $\left.\underline{\text { Scheme 4}}\right)$ :

${ }^{14} \mathrm{NO}\left[\mathrm{BF}_{4}\right]+{ }^{15} \mathrm{NH}_{3}\left(\right.$ at $\left.-50{ }^{\circ} \mathrm{C}\right) \rightarrow{ }^{14} \mathrm{~N}^{15} \mathrm{~N}$ (gas) $+\mathrm{H}_{2} \mathrm{O}+\mathrm{H}\left[\mathrm{BF}_{4}\right]$

This reaction (scheme 4) most likely proceeds through $\mathrm{N}_{2} \mathrm{H}^{+}$intermediate as well.

For $\mathrm{NO}^{+}$in zeolite, once it reacts with $\mathrm{NH}_{3}$ with the release of $\mathrm{N}_{2}$, the Bronsted acid is freed up 15 from $\mathrm{NO}^{+}$and then immediately occupied by ammonia with the formation of $\mathrm{NH}_{4}^{+}$. This "kills" the reactivity as we cannot produce $\mathrm{NO}^{+}$species anymore since their production requires Bronsted acid sites, as evidenced by FTIR (Fig. S4): indeed, no $\mathrm{NO}^{+}$evolves in above-trace-amount upon $\mathrm{NO}+\mathrm{O}_{2}$ reaction on $\mathrm{NH}_{4}$-zeolite (Fig. S4). Only at elevated temperature, when some $\mathrm{NH}_{3}$ can desorb and free up a portion of Bronsted acid sites to re-form $\mathrm{NO}^{+}$, the reaction can proceed catalytically. Indeed, bare H-BEA zeolite is catalytically active for $\mathrm{NO}$ reduction with $\mathrm{NH}_{3}$ in the dry streams (see Fig. S5 for reactivity at 200 and $150{ }^{\circ} \mathrm{C}$ with time-on-stream) (measurable activity is observed).

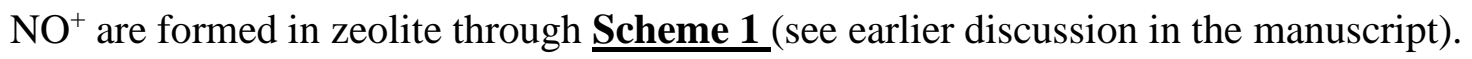

With these new data, we can finally explain the role of $\mathrm{Cu}$ in zeolites for SCR. As is wellestablished in the literature, $\mathrm{Cu}(\mathrm{II})$ ions are required for the active continuous catalytic reaction to proceed [5-20]. In the presence of $\mathrm{NO}, \mathrm{Cu}(\mathrm{II})$ ions can produce $\mathrm{NO}^{+}$via the formal 1-electron reduction of $\mathrm{Cu}(\mathrm{II})$ (analogous chemistry is observed, for example, for Pd(II) in zeolites [30] where Pd(II) was shown to be reduced to $\mathrm{Pd}(\mathrm{I})$ by $\mathrm{NO}$ pulse with concomitant formation of $\mathrm{NO}^{+}$) (Scheme 5):

30

$\mathrm{Zeo} 2 \mathrm{Cu}(\mathrm{II})+\mathrm{NO} \rightarrow \mathrm{Zeo}{ }_{1} \mathrm{Cu}(\mathrm{I})---\mathrm{NO}^{+}-\mathrm{Zeo}{ }_{1}$ 
Fig. 6A shows spectroscopic evidence of $\mathrm{Cu}(\mathrm{II})$ reduction by $\mathrm{NO}$ (when $\mathrm{Cu}(\mathrm{II})$ is first reduced to $\mathrm{Cu}(\mathrm{I})$ before $\mathrm{NO}$ adsorption, basically very little $\mathrm{NO}^{+}$formation occurs because electron transfer does not take place as demonstrated in Fig 6B).

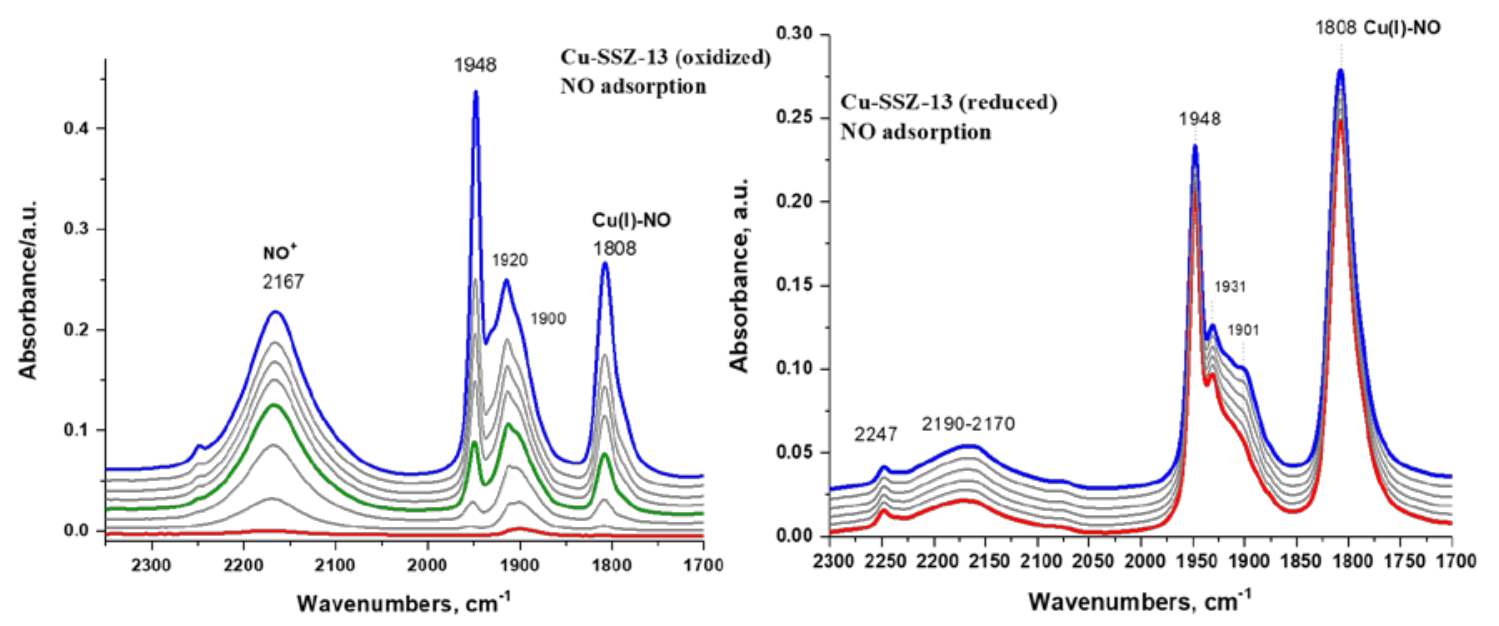

Fig. $5.1 \mathrm{wt} \% \mathrm{Cu} / \mathrm{H}-\mathrm{SSZ}-13$ sample with Si/Al 12. $\underline{\text { A(left): }}$ in-situ FTIR during 1 Torr NO adsorption on oxidized sample. $\mathrm{NO}^{+}$and $\mathrm{Cu}(\mathrm{I})-\mathrm{NO}$ evolve simultaneously from $\mathrm{Cu}(\mathrm{II})$ reduction by $\mathrm{NO} . \underline{\mathrm{B}(\text { right)})}$ : the same sample (tablet) was reduced in the IR cell: 1 Torr NO adsorption (same equilibrium pressure) after reduction.

We have previously been able to refine with solid-state ${ }^{15} \mathrm{NMR}$ studies that indeed, NO is capable of reducing $\mathrm{Cu}(\mathrm{II})$ to $\mathrm{Cu}(\mathrm{I})$ in $\mathrm{H}-\mathrm{SSZ}-13$ : the resulting complex had $\mathrm{Cu}(\mathrm{I})$ and $\mathrm{NO}^{+}$in proximity to each other, with $\mathrm{NO}^{+}$located side-on towards copper ion [20].

Therefore, now we conclude that the role of copper is to promote $\mathrm{NO}^{+}$formation (because Bronsted acid sites get occupied by $\mathrm{NH}_{4}{ }^{+}$after $\mathrm{NO}^{+}$reaction with $\mathrm{NH}_{3}$ on bare $\mathrm{H}$-Zeolite, they cannot contribute to $\mathrm{NO}^{+}$formation as we showed earlier in the text). The resulting $\mathrm{NO}^{+}$reacts with ammonia to reform $\mathrm{N}_{2}$. The $\mathrm{Cu}(\mathrm{I})\left(\mathrm{NH}_{3}\right)_{2}$ complex, in turn, gets re-oxidized back to $\mathrm{Cu}(\mathrm{II})$ with oxygen as the rate-limiting step $[17,18]$.

In summary, this study resolves the previously missing chemistry of the SCR reaction on zeolitic materials and explains the role of $\mathrm{Cu}$ for SCR. For the first time, $\mathrm{NO}^{+}$is shown to be the crucial reactive intermediate without which the reaction cannot proceed. The catalytic reaction is suggested to proceed through the formation of previously unrecognized diazo-complex $\mathrm{N}_{2} \mathrm{H}^{+}$. The role of copper is to be a redox active center which facilitates the formation of $\mathrm{NO}^{+}$from $\mathrm{NO}$ while 
simultaneously getting reduced to $\mathrm{Cu}(\mathrm{I})$. During the rate-limiting step, $\mathrm{Cu}(\mathrm{I})$ gets re-oxidized by $\mathrm{O}_{2}$ to $\mathrm{Cu}(\mathrm{II})$, thus completing the catalytic cycle.

\section{References}

(1) Royal College of Paediatrics and Child Health. Every breath we take-the lifelong impact of air pollution. London: Royal College of Paediatrics and Child Health, 2016.

(2) Sachtler W.M.H. (2002) Catalysis from Art to Science. In: Carley A.F., Davies P.R., Hutchings G.J., Spencer M.S. (eds) Surface Chemistry and Catalysis. Fundamental and Applied Catalysis. Springer, Boston, MA

(3) Khair, M. K.; Majewski, W. A. Diesel emissions and their control; SAE International, Warrendale, 2006.

(4) T. Seiyama, T. Arakawa, T. Matsuda, N. Yamazoe, and Y. Takita, Chem. Lett., 781 (1975)

(5) Zones, S.I. US Patent 4 544 538, 1985.

(6) Ja-Hun Kwak, Russell G Tonkyn, Do Heui Kim, János Szanyi, Charles HF Peden, J. Catal., 2010, 275, 187-190.

(7) I. Bull, A. Moini, G. Koermer, J. Patchett, W. Jaglowski, S. Roth, US Patent US20070134146A1, 2010.

(8) DW Fickel, RF Lobo, The Journal of Physical Chemistry C, 2010, 114 (3), 1633-1640.

(9) J.H. Kwak, D. Tran, S.D. Burton, J. Szanyi, J.H. Lee, C.H.F. Peden J. Catal., 287 (2012), p. 203.

(10)J.H. Kwak, D. Tran, J. Szanyi, C.H.F. Peden, J.H. Lee, Catal. Lett., 142 (2012), p. 295.

(11)S.J. Schmieg, S.H. Oh, C.H. Kim, D.B. Brown, J.H. Lee, C.H.F. Peden, D.H. Kim, Catal. Today, 184 (2012), p. 252.

(12)J.H. Kwak, H.Y. Zhu, J.H. Lee, C.H.F. Peden, J. Szanyi, Chem. Commun., 48 (2012), p. 4758.

(13)F. Gao, J. H. Kwak, J. Szanyi and C. H. F. Peden, Top. Catal., 2013, 56, 1441-1459.

(14)ST Korhonen, DW Fickel, RF Lobo, BM Weckhuysen, AM Beale, Chemical Communications 47 (2), 800-802

(15)F. Gao, E. D. Walter, E. M. Karp, J. Y. Luo, R. G. Tonkyn, J. H. Kwak, J. Szanyi and C. H. F. Peden, J. Catal., 2013, $300,20-29$.

(16)J. H. Kwak, T. Varga, C. H. F. Peden, F. Gao, J. C. Hanson and J. Szanyi, J. Catal., 2014, 314, 83-93.

(17)Gao, F.; Mei, D. H.; Wang, Y. L.; Szanyi, J.; Peden, C. H. F. J. Am. Chem. Soc. 2017, 139, 4935-4942.

(18)Gao, F.; Walter, E. D.; Kollar, M.; Wang, Y.; Szanyi, J.; Peden, C. H. F. J. Catal. 2014, 319, 1-14.

(19)Beale, A. M.; Gao, F.; Lezcano-Gonzalez, I.; Peden, C. H. F.; Szanyi, J. Chem. Soc. Rev. 2015, 44, 7371-7405.

(20)Kwak, J. H.; Lee, J. H.; Burton, S. D.; Lipton, A. S.; Peden, C. H. F.; Szanyi, J., Angew. Chem. Int. Ed. 2013, 52, 9985-9989.

(21)Hadjiivanov, K. I., Catal. Rev. Sci. Eng. 2000, 42, 71-144.

(22)Hadjiivanov, K.; Saussey, J.; Freysz, J. L.; Lavalley, J. C., Catal. Lett. 1998, 52, 103-108.

(23)Szanyi, J.; Paffett, M. T., J. Catal. 1996, 164, 232-245.

(24)A. Zecchina, L. Marchese, S. Bordiga, C. Paze, E. Gianotti, J. Phys. Chem. B, 101 (1997), p. 10128

(25)Negri, C.; Selleri, T.; Borfecchia, E.; Martini, A.; Lomachenko, K. A.; Janssens, T. V.W.; Cutini, M.; Bordiga, S.; Berlier, G. J. Am. Chem. Soc. 2020, 142, 15884-15896.

(26)K. Chakarova, K. Hadjiivanov, J. Phys. Chem. C, 115 (2011), p. 4806

(27)D. Perra, N. Drenchev, K. Chakarova, M.G. Cutrufello, K. Hadjiivanov, RSC Adv., 4 (2014), pp. 56183-56187.

(28)Kazitsyna L. A., Kikot B. S., and Reutov O. A. Bull. Acad. Sci. USSR, Div. Chem. Sci. (Engl. Transl.) 1964, 13, 894.

(29)J Szanyi, JH Kwak, CHF Peden, The Journal of Physical Chemistry B 108 (12), 3746-3753.

(30)Khivantsev, K.; Jaegers, N. R.; Koleva, I. Z.; Aleksandrov, H. A.; Kovarik, L.; Engelhard, M.; Gao, F.; Wang, Y.; Vayssilov, G. N.; Szanyi, J. J. Phys. Chem. C 2020, 124 (1), 309-321.

\section{Acknowledgments:}

Konstantin Khivantsev is grateful to Dr. Libor Kovarik for fruitful discussions and movitation!

The research at PNNL was supported by the U.S. Department of Energy, Office of Basic Energy

Sciences, Division of Chemical Sciences, Biosciences, and Geosciences Catalysis Program (DE- 
AC05-RL01830, FW-47319). Experiments were conducted in the Environmental Molecular Sciences Laboratory (EMSL), a national scientific user facility sponsored by the Department of Energy's Office of Biological and Environmental Research at Pacific Northwest National Laboratory (PNNL). PNNL is a multi-program national laboratory operated for the DOE by 5 Battelle Memorial Institute under Contract DE-AC06-76RL01830.

Author contributions: All authors participated in the planning of experiments, data collection and analysis, and writing of the manuscript.

Competing interests: Authors have no conflicts to eclair.

Data and materials availability: All data is available in the main text or the supplementary materials. 


\section{Supplementary Materials:}

Materials and Methods

Supplementary text

Figures S1-S7

\section{Identification of the mechanism of NO reduction with ammonia (SCR) on zeolite catalysts}

Authors: Konstantin Khivantsev, ${ }^{1, \dagger}, *$ Ja-Hun Kwak, ${ }^{2, \dagger, *}$ Nicholas R. Jaegers, ${ }^{1}$ Miroslaw A. Derewinski, ${ }^{1,3}$ Janos Szanyi, ${ }^{1, \dagger}, *$

\section{Affiliations:}

${ }^{1}$ Institute for Integrated Catalysis, Pacific Northwest National Laboratory, Richland, WA 99352, USA.

${ }^{2}$ Ulsan National Institute of Science and Technology (UNIST), South Korea.

${ }^{3}$ Jerzy Haber Institute of Catalysis and Surface Chemistry, Polish Academy of Sciences, Krakow 30-239, Poland

15 * Correspondence to: K.K. E-mail: Konstantin.Khivantsev@pnnl.gov . J.-H. K. E-mail: jhkwak@unist.ac.kr.J.Sz.E-mail: Janos.Szanyi@pnnl.gov;

$\dagger$ These authors contributed equally to the manuscript: KK, JHK, JSz

\section{Materials and methods}

$\mathrm{BEA}$ with $\mathrm{Si} / \mathrm{Al}$ ratio $~ 15$ was synthesized in the presence of fluoride anions according to a procedure developed by Camblor et al. [S1] The gel composition was as follows $\mathrm{SiO}_{2}$ : $\mathrm{xAl}_{2} \mathrm{O}_{3}:(0.54+2 \mathrm{x}) \mathrm{TEAOH}:(0.54+2 \mathrm{x}) \mathrm{HF}:(7+2 \mathrm{x}) \mathrm{H}_{2} \mathrm{O}$. The absence of alkali cations requires only a calcination step $\left(550{ }^{\circ} \mathrm{C}\right.$ in flowing air), decomposing the organic cation (TEA $\left.{ }^{+}\right)$to convert it into Brønsted acidic H-Form.

Na/SSZ-13 zeolite with Si/Al 12 was hydrothermally synthesized using the following recipe: 0.8 $\mathrm{g}$ of $\mathrm{NaOH}$ (Sigma Aldrich, $\geq 99 \%$ ) was dissolved in $50 \mathrm{ml}$ of deionized water. $17 \mathrm{~g}$ of TMAda-OH (Sachem Inc., 25\% N,N,N-trimethyl-1-adamantyl ammonium hydroxide) was added as structure directing agent. $0.75 \mathrm{~g}$ of $\mathrm{Al}(\mathrm{OH})_{3}$ (Sigma Aldrich, $54 \% \mathrm{Al}_{2} \mathrm{O}_{3}$ ) was slowly added to the solution and stirred at $400 \mathrm{rpm}$ until it was completely dissolved. $20.0 \mathrm{~g}$ of LUDOX HS-30 colloidal silica (Sigma Aldrich, $30 \mathrm{wt} \%$ suspension in $\mathrm{H}_{2} \mathrm{O}$ ) was added slowly to the solution until a uniform gel was formed. The obtained gel was sealed in a $125 \mathrm{~mL}$ Teflon-lined stainless steel autoclave with a magnetic stirring 
bar. Hydrothermal synthesis was carried out at $160{ }^{\circ} \mathrm{C}$ under continuous stirring at $400 \mathrm{rpm}$ for 4 days. After synthesis, the zeolite cake was separated from the suspension by centrifugation, and washed with deionized water. It was then dried at $80{ }^{\circ} \mathrm{C}$ under $\mathrm{N}_{2}$ flow overnight, and calcined in air at $550{ }^{\circ} \mathrm{C}$ for $5 \mathrm{~h}$ in order to remove the SDA. $\mathrm{NH}_{4} / \mathrm{SSZ}-13$ was obtained by ion exchange of the as-prepared $\mathrm{Na} / \mathrm{SSZ}-13$ zeolite with $1 \mathrm{M} \mathrm{NH}_{4} \mathrm{NO}_{3}$ solution at $80^{\circ} \mathrm{C}$ for $5 \mathrm{~h}$. The process was repeated three times. $\mathrm{H}$-form of zeolite was obtained by calcining in air at $550^{\circ} \mathrm{C}$ for 5 hours. Ion-exchange with $\mathrm{Cu}$ (II) to produce $\mathrm{Cu} / \mathrm{SSZ}-13$ was performed in the presence of copper nitrate. The resulting sample was calcined at $550^{\circ} \mathrm{C}$ in air.

$\mathrm{NO}\left[\mathrm{BF}_{4}\right]$ nitrosyl tetrafluoroborate (99\%) was purchased from Strem Chemicals and stored cold in the absence of moisture.

All the chemicals used were the highest-grade purity available.

HAADF-STEM analysis was performed with a FEI Titan 80-300 microscope operated at 300 $\mathrm{kV}$. The instrument is equipped with a CEOS GmbH double-hexapole aberration corrector for the probe-forming lens, which allows for imaging with $0.1 \mathrm{~nm}$ resolution in scanning transmission electron microscopy mode (STEM). The images were acquired with a high angle annular dark field (HAADF) detector with inner collection angle set to $52 \mathrm{mrad}$.

Helium ion microscopy (HIM) images were obtained using $35 \mathrm{keV}$ He ions with 0.1 pA beam current at normal incidence. Secondary electrons were detected using an Everhart-Thornley detector. For HIM imaging, a very thin layer of carbon $(<1 \mathrm{~nm})$ was coated using a carbon sputter deposition system as the samples were completely insulating. The instrument resolution was $0.35 \mathrm{~nm}$.

The in-situ static transmission IR experiments were conducted in a home-built cell housed in the sample compartment of a Bruker Vertex 80 spectrometer, equipped with an MCT detector and operated at $4 \mathrm{~cm}^{-1}$ resolution. Mass-spectrometer is attached to the cell to monitor different gaseous species present. The powder sample was pressed onto a tungsten mesh which, in turn, was mounted onto a copper heating assembly attached to a ceramic feedthrough. The sample could be resistively heated, and the sample temperature was monitored by a thermocouple spot welded onto the top center of the $\mathrm{W}$ grid. The cold finger on the glass bulb containing CO (99.995\%) was cooled with liquid nitrogen to eliminate any contamination originating from metal carbonyls, while NO (99.95\%) was cleaned with multiple freeze-pump-thaw cycles. ${ }^{15} \mathrm{NH}_{3}(15 \mathrm{~N}, 98 \%)$ was purchased from Cambridge Isotopes. Special research-grade oxygen (purity 99.995\%) was purchased from Oxarc. 
The NO reduction by ammonia (in the presence of oxygen) was carried out in a typical quartz the plug-flow reactor. $120 \mathrm{mg}$ of $\mathrm{H}$-zeolites was used for reaction tests. The composition of the gas flowing through the catalyst was $360 \mathrm{ppm} \mathrm{NH}_{3}, 360 \mathrm{ppm} \mathrm{NO} \sim 12 \% \mathrm{O}_{2}$ balanced with nitrogen. The total flow rate was $\sim 300 \mathrm{sscm} / \mathrm{min}$. Concentrations of reactants and products were measured by the MKS FTIR analyzer.

References: S1 M.A. Camblor, A. Corma, S. Valencia Synthesis in fluoride media and characterisation of aluminosilicate zeolite beta, J. Mater. Chem., 8 (1998), pp. 2137-2145 


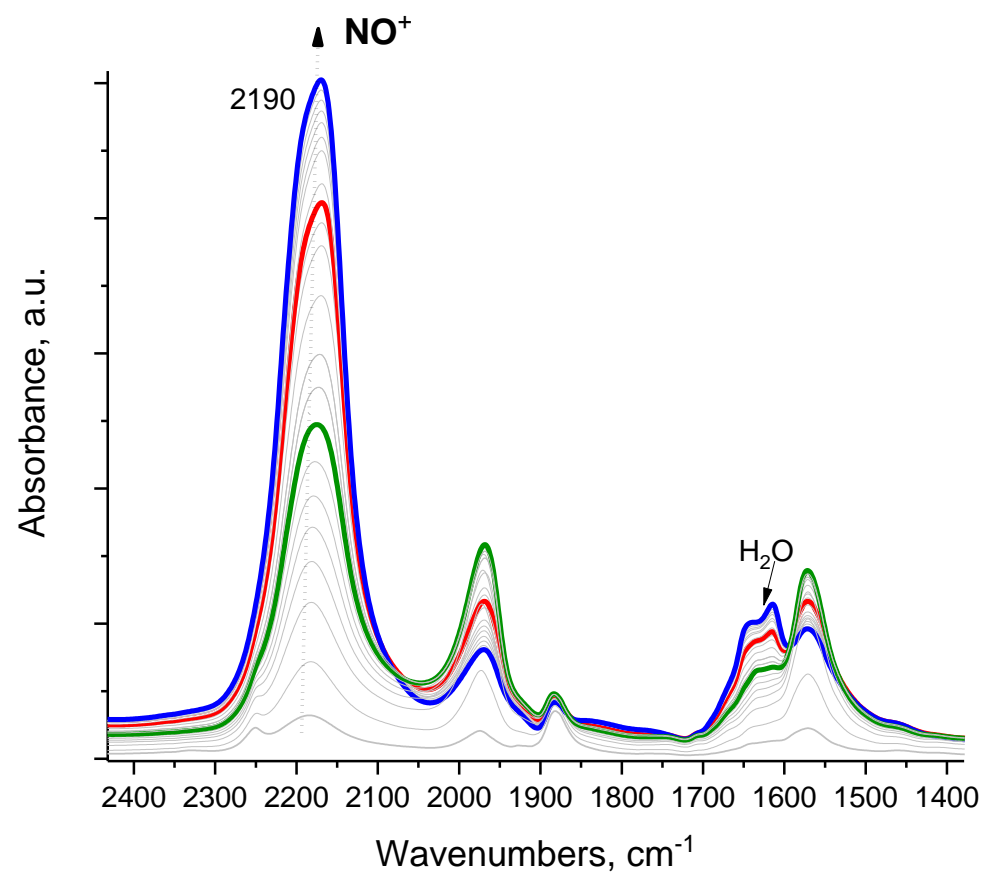

Fig. S1. In-situ FTIR during sequential NO (0.5 Torr) and $\mathrm{O}_{2}$ (0.1 Torr) co-adsorption on H-SSZ13 with $\mathrm{Si} / \mathrm{Al} 12$ at room temperature.

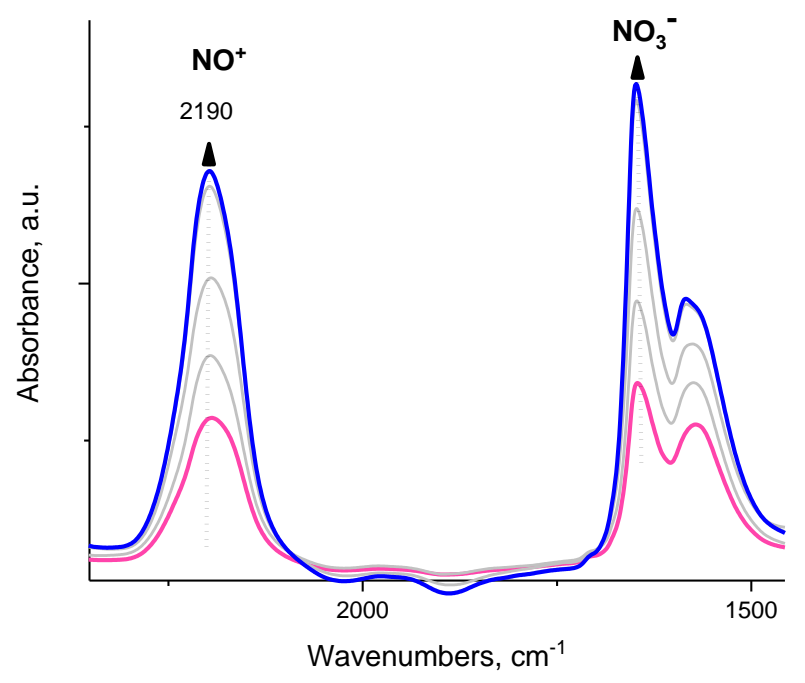

Fig. S2. In-situ FTIR during sequential $\mathrm{NO}_{2}$ (0.5 Torr) on H-SSZ-13 with $\mathrm{Si} / \mathrm{Al} \sim 12$ at room temperature. $\mathrm{NO}_{2}$ forms $\mathrm{N}_{2} \mathrm{O}_{4}$ in the pores and immediately reacts with $\mathrm{H}$-SSZ-13 to form $\mathrm{NO}^{+}$ and $\mathrm{HNO}_{3}$. 


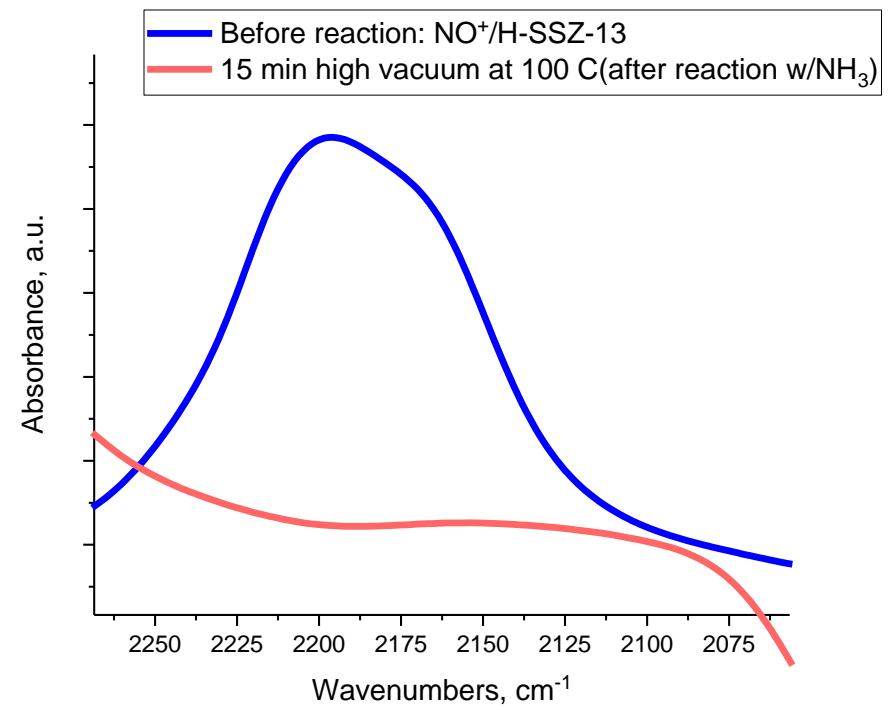

Fig. S3. Continuing from Fig 5 in the Main Text. FTIR of the N-O stretching region of $\mathrm{NO}^{+} / \mathrm{H}-\mathrm{SSZ}-13$ system before reaction with ammonia, and after reaction with ammonia (at room temperature), and after pulling high vacuum at $100{ }^{\circ} \mathrm{C}$ for 15 minutes.

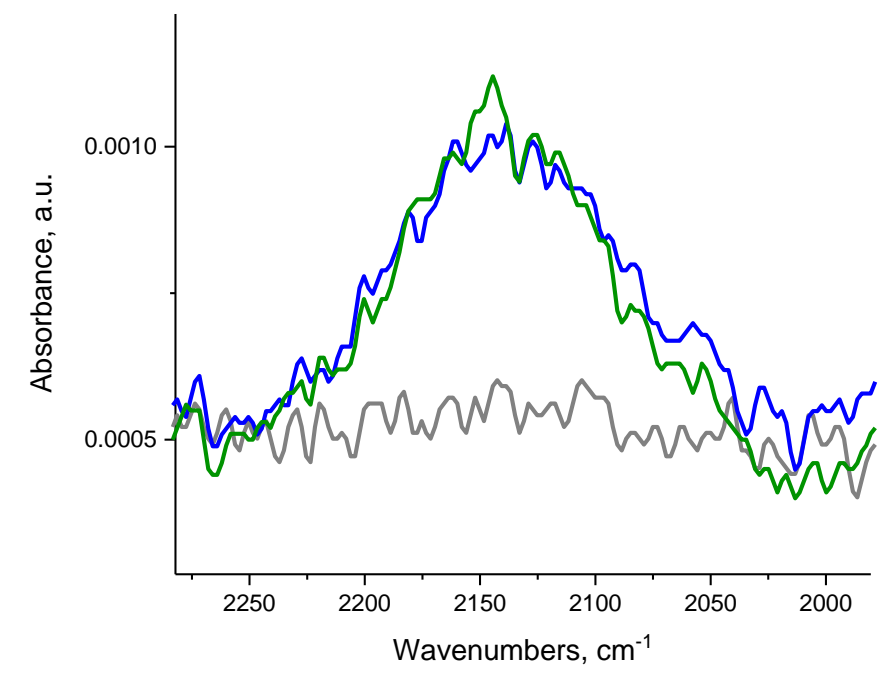

Figs. S4. Continuing FTIR experiments after the ones performed in Fig 2A. After reaction between $\mathrm{NO}^{+} / \mathrm{H}$-BEA with ${ }^{15} \mathrm{NH}_{3}$, the sample was vacuumed at room temperature and new baseline was collected (gray spectrum). 2 Torr $\mathrm{NO}+0.7$ Torr $\mathrm{O}_{2}$ were then reacted with the sample: the resulting spectra (green and blue) show that because $\mathrm{NH}_{3}$ occupied Bronsted acid sites of zeolite with the formation of $\mathrm{NH}_{4}$-Zeolite (ammonia is strongly adsorbed and cannot be desorbed at room temperature even to a small extent), only extremely small amounts of $\mathrm{NO}^{+}$can be formed (intensities barely above the noise level). 


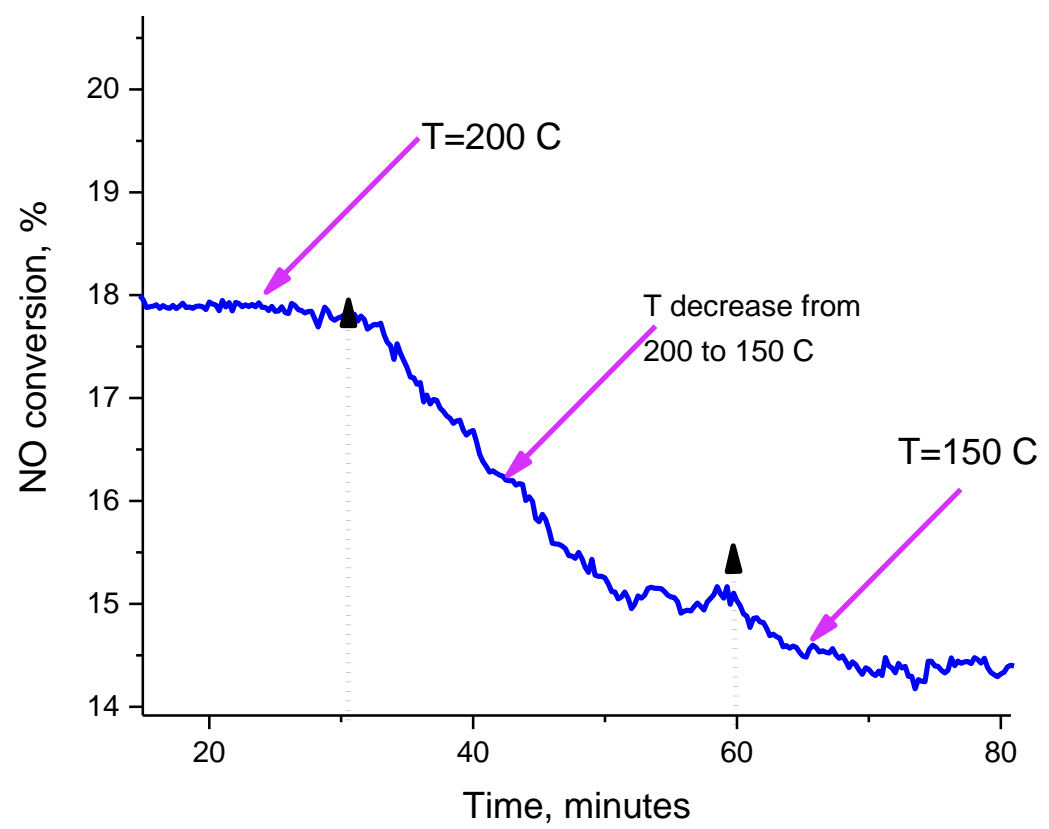

Figs. S5. NO conversion (\%) vs time-on-stream for $\mathrm{H}-\mathrm{BEA} \mathrm{Si/Al} 15$ sample under dry conditions (conditions specified in experimental section). 


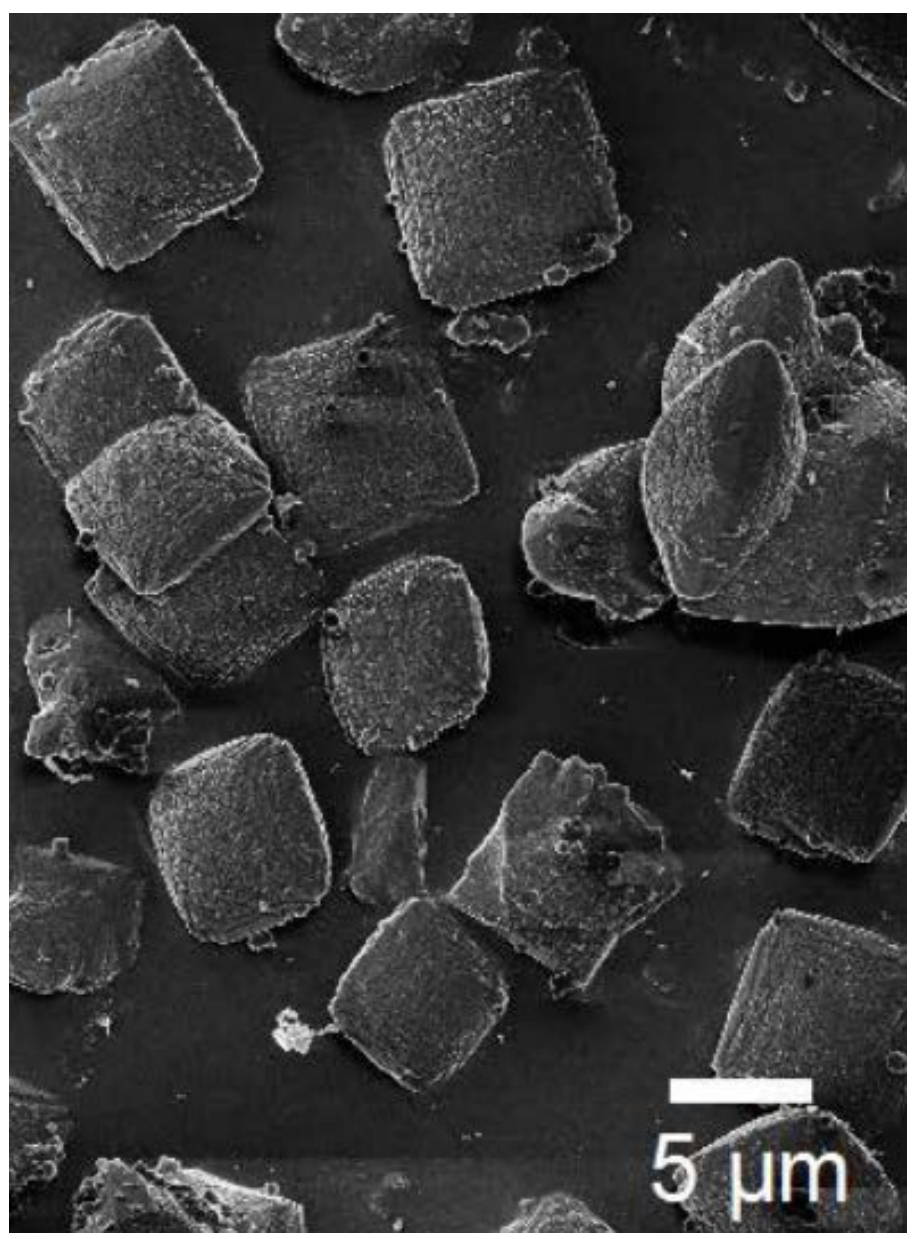

Fig. S6. Typical Helium Ion Microscopy (HIM) image of H-BEA crystals with Si/Al 15 . 


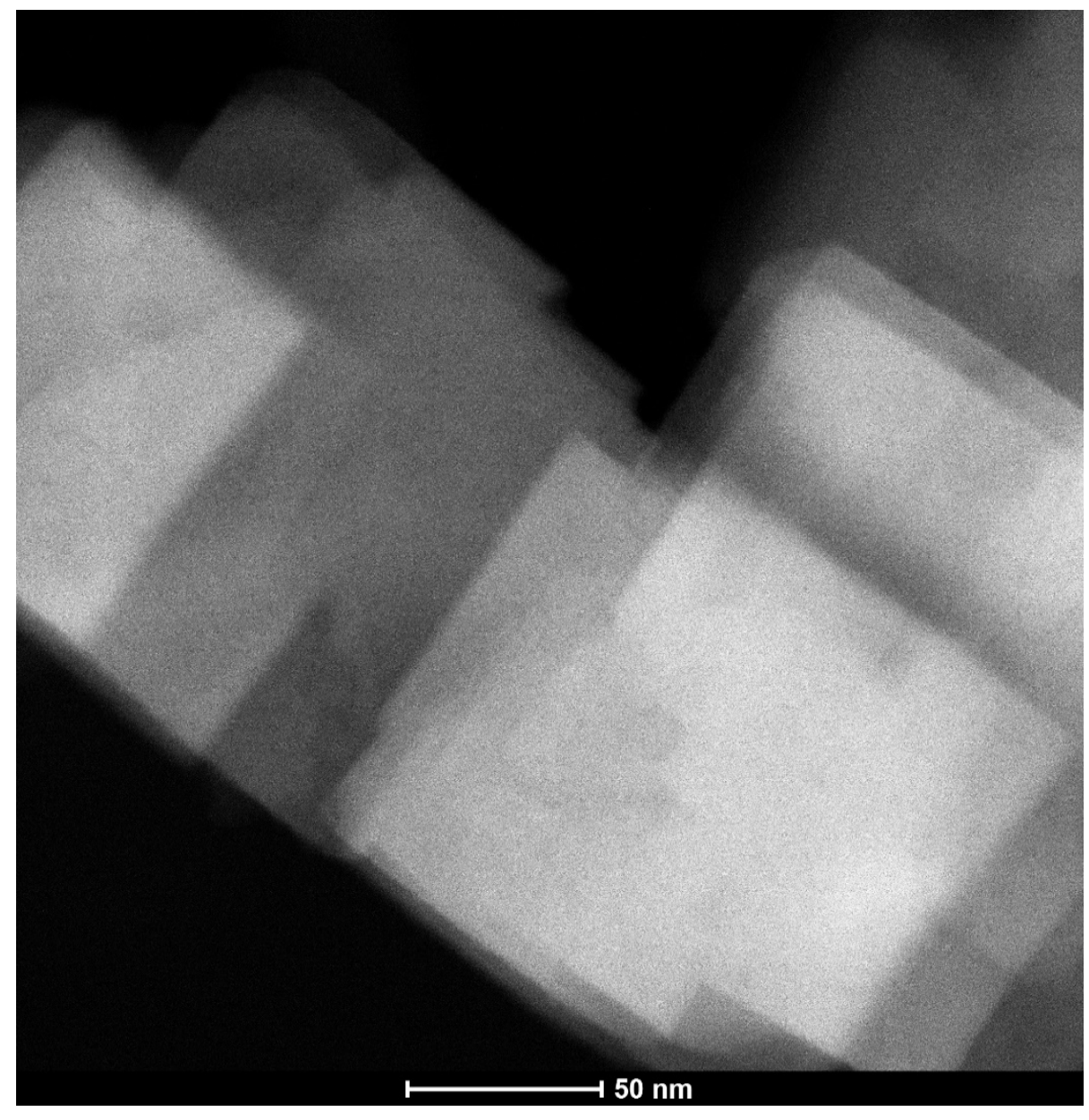

Fig. S7. Typical HAADF-STEM images of SSZ-13 crystals. 